\title{
SITUS NEOLITIK MALLAWA MAROS, SULAWESI SELATAN (Suatu Hasil Analisis Keterkaitan antara Artefak dengan Sumber Daya Lingkungan)

\author{
Neolithic Site at Mallawa Maros of South Sulawesi \\ (A Result of Relevancy Analysis Between The Artefacts and The Environment \\ Resources)
}

\author{
Hasanuddin \\ Balai Arkeologi Sulawesi Selatan, JI. Pajjaiyang No.13, Sudiang Raya, Makassar 90552, \\ e-mail: udin.balar@gmail.com
}

\section{INFO ARTIKEL}

\section{Histori artikel}

Diterima: 2 Februari 2017

Direvisi: 6 April 2017

Disetujui: 12 Juni 2017

\section{Keywords:}

Mallawa,

Neolithic,

pottery analysis

\author{
Kata kunci: \\ Mallawa, \\ Neolitik \\ analisis gerabah
}

\begin{abstract}
The Mallawa is an open site located in the eastern part of Maros, South Sulawesi. The topography of Mallawa site is wavy and took place in a hilly area. Dating of the site using C14 Analysis showed that the site is about $3550 \pm 130 \mathrm{BP}$ and $2710 \pm 170 \mathrm{BP}$ and $2281 \pm 46 \mathrm{BP}$. The point of this site, besides of its plenty artifacts that signifying occupied-densely site of some hills, the site is also located nearby caves of Maros. From the perspective of periodization, Mallawa site relatively younger compared to occupancy period in Maros caves. It is likely to say that the occupancy of Mallawa cave is the further stage in development of past life that characterized by its material culture remains. Several pottery findings possesses various of interesting forms and ornaments. In this research has also found several interesting findings such as pottery fragments, beads and stone artifacts. The excavation brings out more findings then the surficial findings. Through $X R D$ analysis, SEM and also, XRF of the pottery and soil sample shows that Mallawa pottery were made and produced by the Mallawa themselves and the people surrounding based on the fact that the pottery contains the same mineral with the soil that surrounding this site.
\end{abstract}

\begin{abstract}
ABSTRAK
Mallawa adalah situs terbuka yang terletak di bagian timur Maros, Sulawesi Selatan. Topografi situs Mallawa bergelombang dan terletak di daerah perbukitan. Pertanggalan situs dengan menggunakan Analisis C14 menunjukkan bahwa situs ini berumur sekitar $3550 \pm 130$ BP dan $2710 \pm$ $170 \mathrm{BP}$ dan $2281 \pm 46$ BP. Bagian penting dari situs ini, selain dari temuan artefak yang menandakan tempat berpenduduk padat di beberapa bukit, situs ini juga terletak di dekat gua-gua Maros. Dari segi periodisasi, situs Mallawa relatif lebih muda dibandingkan dengan masa hunian di gua Maros. Kemungkinan besar dikatakan bahwa hunian situs Mallawa merupakan tahap lanjutan dalam pengembangan kehidupan lampau yang ditandai oleh budaya materialnya. Beberapa temuan gerabah memiliki berbagai bentuk dan ornamen yang menarik. Dalam penelitian ini juga ditemukan beberapa temuan menarik seperti fragmen gerabah, manik-manik dan artefak batu. Penggalian tersebut menghasilkan lebih banyak temuan. Melalui analisis XRD, SEM dan juga, XRF dari gerabah dan sampel tanah menunjukkan bahwa gerabah Mallawa dibuat dan diproduksi di Mallawa sendiri berdasarkan fakta bahwa gerabah mengandung mineral yang sama dengan tanah di sekitar lokasi ini.
\end{abstract}




\section{PENDAHULUAN}

Situs Mallawa terletak $92 \mathrm{~km}$ sebelah timur laut Kota Makassar, atau $62 \mathrm{~km}$ sebelah timur Kabupaten Maros. Morfologi situs Mallawa agak bergelombang dan diantaranya terdapat beberapa perbukitan. Potensi situs Mallawa dilaporkan pertama kali oleh tim survei mahasiswa arkeologi Universitas Hasanuddin pada 1994 yang melakukan eksplorasi di situs tersebut. Selanjutnya Balai Arkeologi Sulawesi Selatan (pada waktu itu bernama Balai Arkeologi Ujungpandang) bekerjasama dengan Puslit Arkenas (Pusat Penelitian Arkeologi Nasional) yang dipimpin oleh Fadlan tahun 1995 melakukan penelitian bidang arkeometri untuk mengetahui jenis batuan artefak. Dari penelitian itu menunjukkan bahwa jenis batuan yang digunakan berasal dari jenis batu basal yang banyak ditemukan di sekitar situs. Hal demikian mencerminkan pula bahwa pendukung kebudayaan Mallawa memanfaatkan sumberdaya batuan sebagai bahan baku pembuatan alat. Pada tahun itu pula, Balai Pelestarian Cagar Budaya Makassar (pada waktu itu bernama Suaka Peninggalan Sejarah dan Purbakala) melakukan survei untuk kepentingan inventarisasi situs.

Selanjutnya tahun 1999 Pusat Penelitian Arkeologi Nasional bekerjasama dengan Jurusan Arkeologi Universitas Hasanuddin mengadakan penelitian berupa ekskavasi dan pemetaan situs di sektor Bulu Bakung. Penelitian tersebut menghasilkan temuan kapak persegi, manik-manik, tembikar (berhias dan berslip merah) (Mahmud, 2008: 119). Penelitian penyelamatan dilakukan oleh Balai Pelestarian Cagar Budaya (BPCB) Makassar pada 2012. Adapun tujuan survei penyelamatan tersebut adalah untuk penentuan batas situs dan merekam kondisi kekinian situs dan tinggalan yang ada di dalamnya. Survei penyelamatan tersebut berhasil menjaring rekaman temuan berupa artefak batu dari berbagai jenis dan bahan yang jumlahnya mencapai 1818 serta fragmen tembikar yang jumlahnya mencapai 471 , tersebar pada dua lokasi, yaitu Bulu Bakung dan sebuah bukit di sisi timurnya (Tim BPCB, 2012). Selanjutnya 2014 Balai Arkeologi Sulawesi Selatan melakukan survei dan ekskavasi di Bulu Bakung (dalam situs Mallawa) serta menemukan sejumlah lapisan budaya yang mengandung artefak batu, manikmanik, dan tembikar (polos, berhias, dan beslip) (Tim Balar Sulsel, 2014).

Posisi geografis situs Mallawa yang merupakan bagian gugusan pegunungan kars Maros, merupakan bentuk topografi yang memiliki indikasi kehidupan prasejarah terutama di gua-gua. Selama ini kehidupan di gua-gua (leang) prasejarah Maros seperti Leang Lompoa, Barugayya 1, Barugayya 2, Jing, Timpuseng, Jarie, Sampeang yang memiliki lukisan pada kisaran masa Plestosen Akhir 
(Aubert dkk. 2014: 2-4). Dari penelitian tersebut menunjukkan bahwa lapisan budaya beberapa gua di Sulawesi Selatan berasal dari masa Plestosen hingga masa Holosen dengan karakter budayanya masing-masing. Bentuk topografi Maros juga memiliki perbukitan seperti di Mallawa yang dapat mengungkapkan beberapa isu menarik berkaitan dengan persebaran manusia berbahasa Austronesia di Mallawa, diantaranya: bagaimana hubungan antara lingkungan fisik Mallawa dengan hadirnya sejumlah temuan artefak batu maupun tembikar.

Situs ini menarik karena selain dari artefak berlimpah yang dapat menandai situs padat huni meliputi beberapa bukit, situs ini juga berdekatan dengan gua-gua di Maros. Situs Mallawa mungkin telah dihuni oleh migrasi gelombang kemudian oleh generasi selanjutnya yang tersebar dari zona tertentu dan didukung oleh artefak batu dan tembikar. Kapak dan pahat batu yang sudah diupam serta tembikar merupakan indikasi kuat tentang hunian para kelompok penutur Austronesia. Bagian lain yang menarik adalah bentuk dan dekorasi dari tembikar yang ditemukan di situs ini menunjukkan banyak kemiripan dengan tembikar yang ditemukan di situs Minanga Sipakko (Mahmud, 2008: 125-126).

Selain itu, singkapan batu kapur silisifikasi dan batuan sedimen ditemukan cukup tersebar di sungaisungai di sekitar situs. Beberapa jenis batu alam dalam lingkungan ini mirip dengan yang digunakan sebagai bahan artefak litik yang ditemukan di situs Mallawa (Fadhlan, 2012). Selama ini pertanggalan yang dihasilkan oleh penelitian Simanjuntak (2008) melalui analisis C14 adalah $3580 \pm 130 \mathrm{BP}$ dan $2710 \pm 170$ BP. Hasil itu didasarkan uji karbon yang diperoleh dari ekskavasi di puncak Bulu Bakung. Sementara penelitian yang dilakukan oleh Budianto Hakim, dkk (2009) di Mallawa diperoleh pertanggalan $2281 \pm 46 \mathrm{BP}$ yang sampel karbonnya diperoleh dari hasil ekskavasi di bagian kaki Bulu Bakung.

\section{Metode}

Berdasarkan hasil observasi, maka dilakukan penentuan kotak ekskavasi. Teknik ekskavasi yang diterapkan adalah teknik box, sedangkan untuk pendalaman digunakan teknik spit dengan interval $10 \mathrm{~cm}$. Dalam pencapaian hasil analisis yang maksimal, maka dilakukan pencuplikan sampel temuan survei dan ekskavasi secara acak. Meskipun bersifat acak, namun tetap mempertimbangkan bentuk, jenis dan kualitas temuan. Teknik ini diterapkan dengan pertimbangan kondisi sebaran temuan permukaan yang cukup merata. Sampel yang dicuplik adalah sampel yang sudah terseleksi. Analisis fragmen tembikar dilakukan di laboratorium Universitas Negeri Makassar, Departemen Fisika dengan menggunakan 
analisis X-Ray Diffraction (XRD)dan $X$-Ray Fluorescence (XRF) serta Scanning Electron Microscope (SEM). Pengamatan untuk mengetahui teknik hias dapat dilakukan dengan cara mengamati irisan dinding permukaan tembikar

Selain itu, dilakukan pula perbandingan data dengan cara mencari persamaan dan perbedaan artefak batu dan fragmen tembikar di situs Mallawa dan selanjutnya dibandingkan dengan situs-situs pada DAS Karama di Sulawesi Barat. Tahapan terakhir adalah penjelasan data yang dilakukan dengan cara menyederhanakan semua gejala dan data yang telah diidentifikasi, diklasifikasi, dan dikomparasi untuk menghasilkan kesimpulan. Kesimpulan yang dihasilkan merupakan jawaban dari permasalahan penelitian yang diajukan.

\section{Data Geologi}

$\begin{array}{lrr}\text { Menurut } & \text { Fadhlan } & \text { (1995), } \\ \text { secara umum keadaan } & \text { bentang } \\ \text { alam (morfologi) } & \text { daerah } & \text { Mallawa } \\ \text { memperlihatkan } & \text { kondisi } & \text { dataran }\end{array}$ rendah dengan ketinggian antara 50 hingga 500 meter di atas permukaan air laut. Satuan morfologi dataran dicirikan oleh bentuk permukaan yang sangat landai dan datar, dengan prosentase kemiringan lereng antara 0-2\%, serta bentuk lembah yang sangat lebar. Satuan morfologi dataran pada umumnya ditempati oleh penduduk sekarang ini sebagai wilayah pemukiman dan areal persawahan atau ladang. Satuan morfologi bergelombang lemah dicirikan dengan bentuk bukit yang landai, relief halus, lembah yang melebar dan menyerupai huruf "U", bentuk bukit yang agak membulat atau bergelombang lemah dengan prosentase kemiringan lereng antara 2-8\%. Sebagian besar daerah ini ditumbuhi oleh semak belukar, dan di beberapa tempat berpotensi sebagai lahan pertanian. Satuan morfologi bergelombang kuat dicirikan dengan lereng yang terjal, bentuk relief masih agak kasar dengan persentase kemiringan lereng antara $8-16 \%$. Satuan ini ditumbuhi oleh semak belukar dan beberapa jenis pohonpohon yang besar. Sungai-sungai yang mengalir di daerah ini adalah Sungai Mallawa dan Sungai Walennae dan beberapa anak-anak sungai kecil lainnya.

Geologi situs Mallawa dipengaruhi oleh formasi geologi Mallawa terletak di atas pembentukan Balangbaru dari periode Miosen, terdiri dari batuan sedimen, batubara, tanah liat dan batu pasir dari periode Eosen Bawah (Fadhlan, 1995). Lebih jauh, Fadhlan (1995) menyebutkan bahwa situs Mallawa terdiri atas satuan batuan aluvial dan batuan beku. Satuan aluvial terdiri dari lempung, lanau, pasir dan kerikil. Endapan aluvial tersebar di sekitar kaki-kaki bukit dan bagian timur yang membentuk morfologi dataran dan dimanfaatkan oleh penduduk sebagai lahan pertanian. Endapan 
aluvial ini merupakan hasil pelapukan batuan penyusun daerah Mallawa dan sekitarnya yang berumur Holosen. Pengmatan terhadap batuan beku memperlihatkan warna hitam keabuabuan.Kenampakanlapanganterhadap batuan sedimen memperlihatkan warna putih dengan warna lapuk putih kecoklatan. Kenampakan lapangan terhadap batuan-batuan piroklastik adalah memperlihatkan warna putih kekuningan dengan warna pelapukan kuning kecoklatan.

\section{Kondisi Situs dan Sampel Analisis}

Situs Mallawa dibagi menjadi dua sektor, yaitu Bulu Bakung dan Tana Ugi. Secara administrasif keduanya berada di Kelurahan Sabila, Kecamatan Mallawa, Kabupaten Maros. Kedua sektor tersebut memiliki karakter lingkungan yang sama berupa deretan bukit, banyak ditumbuhi semak belukar dan padang rumput dengan sedikit pohon besar. Selain itu, berada di pinggir sungai kecil dengan debit air yang kurang dan meluap pada saat musim hujan. Sungai ini mengalir ke arah timur hingga bermuara di Sungai
Walennae. Kedua sektor masingmasing terletak di atas bukit yang berbeda, memiliki ciri-ciri temuan dari masa bercocok tanam atau umumnya dikenal masa Neolitik seperti beliung dan tembikar.
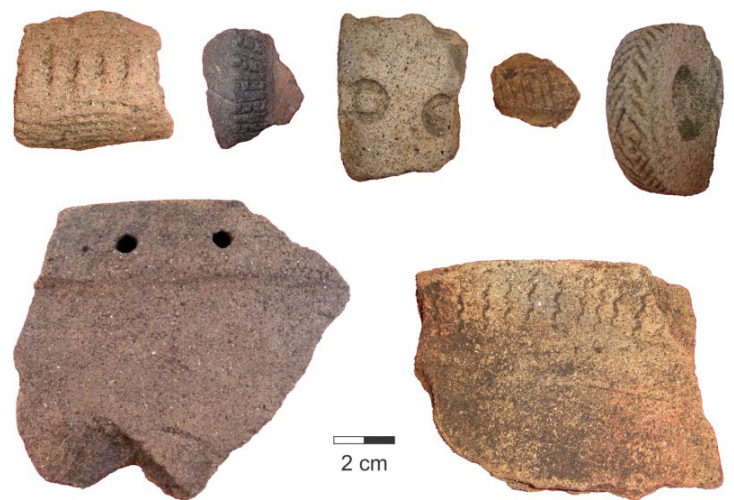

Gambar 3. Beberapa temuan fragmen tembikar berhias sektor Bulu Bakung (temuan survei) (dokumentasi Balar Sulsel, 2014).
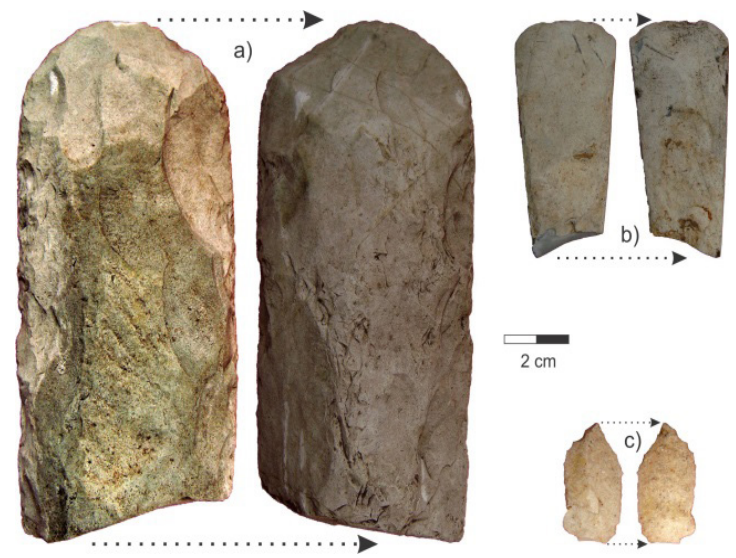

Gambar 2. Temuan survei di sektor Bulu Bakung berupa artefak batu. a) beliung dan b) pahat batu terbuat dari bahan batuan basalt; serta c) artefak serpih bahan batuan chert (dokumentasi Balar Sulsel, 2014).

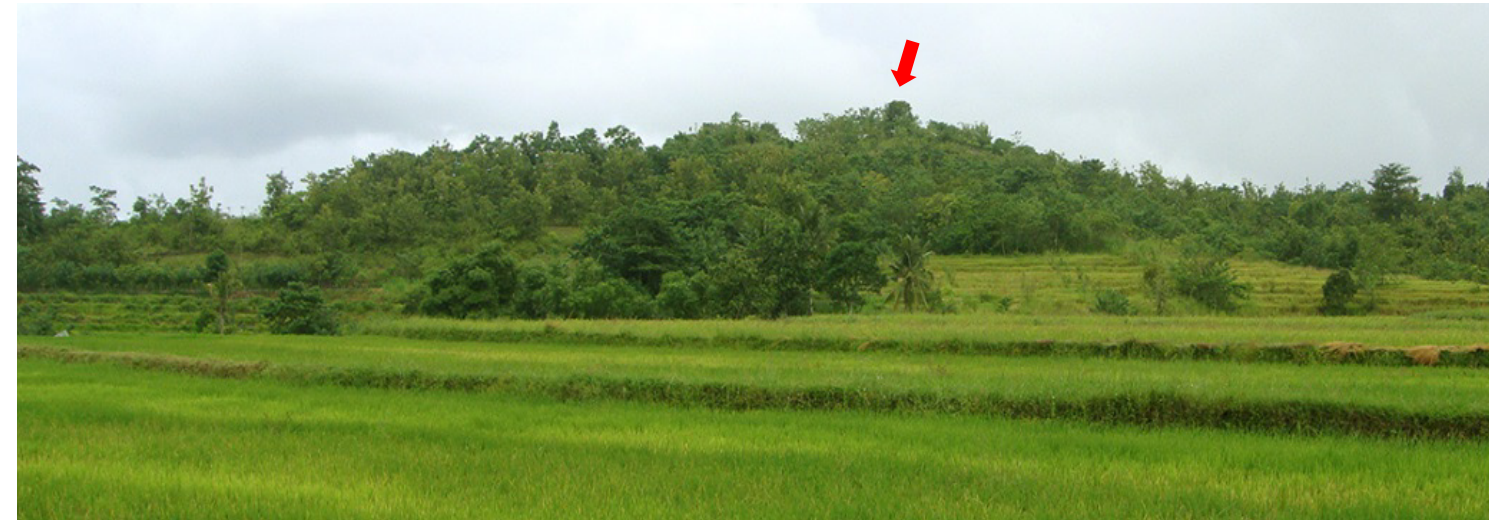

Gambar 1. Situs Mallawa (Maros) Sektor Bulu Bakung (tanda panah), tampak dari utara (dokumentasi Balar Sulsel, 2014). 
Puncak bukit pertama, Bulu Bakung (gambar 1), memiliki jenis temuan berupa fragmen tembikar, artefak batu, fragmen tulang dan lumpang batu. Jenis temuan adalah beliung dan pahat batu (gambar 2) dan fragmen tembikar (gambar 3). Konsentrasi temuan fragmen tembikar berada pada punggungan dan lereng bukit sebelah utara puncak bukit tepatnya di areal perkebunan milik Bapak Andi Sommeng. Di atas puncak Bulu Bakung ditemukan sebaran tembikar yang cukup padat di permukaan (gambar 3). Secara astronomi terletak pada $04^{\circ} 51^{\prime} 19.4$ " LS dan $119^{\circ} 55^{\prime} 20.1^{\prime \prime}$ BT dengan elevasi $435 \mathrm{~m}$ dpl. Situs Mallawa berada sekitar $2 \mathrm{~km}$ dari anak Sungai Walennae yang mengalir dari wilayah Kabupaten Soppeng.

Puncak bukit kedua, sektor Tana Ugi, terletak di sebelah selatan bukit pertama dengan jarak \pm 168 meter. Secara astronomis terletak pada $04^{\circ}$ 51' 6.9" Lintang Selatan dan $119^{\circ} 55^{\prime}$ 37.2" Bujur Timur dengan elevasi $391 \mathrm{~m}$ dpl, ditumbuhi semak dan hutan jati sehingga sangat sulit untuk dicapai. Dengan demikian, survei dilakukan hanya di sekitar lereng bukit. Survei di situs Tana Ugi ditemukan artefak batu dan fragmen tembikar (gambar 4). Artefak batu terdiri dari 25 kapak, lima serpih dipakai dan empat tatal. Berdasaran analisis kuantitatif diperoleh kategori bahan yaitu $68 \%$ batuan sabak dan $32 \%$ dari batuan basalt. Kedua jenis batuan tersebut cukup tersedia yaitu sekitar 200 meter dari situs Tanah Ugi. Hal ini memperlihatkan bahwa pembuatan kapak batu memanfaatkan sumber batuan yang ada di area situs untuk kebutuhan manusia. Kapak batu berukuran rata-rata panjang $5,4 \mathrm{~cm}$, lebar $4 \mathrm{~cm}$, dan tebal $1,3 \mathrm{~cm}$. Kondisi temuan artefak batu adalah $24 \%$ utuh, $32 \%$ patah pada bagian pangkal, $32 \%$ tajaman rusak dan $12 \%$ patah pada bagian pangkal dan tajaman. Melihat tingginya persentase kerusakan kapak batu, diduga kuat disebabkan oleh intensitas pemakaian yang cukup tinggi atau mungkin setelah mengalami proses transformasi. Temuan serpih dipakai yang telah dianalisis berdasarkan atribut bentuk dan tajaman, digunakan sebagai penyerut, gurdi dan alat tusuk. Bahan yang digunakan untuk pembuatan terdiri dari chert (rijang), basalt dan sabak.

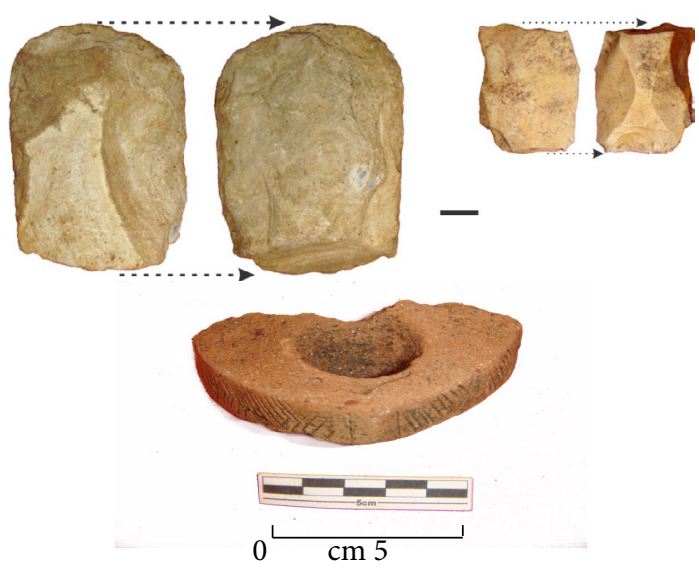

Gambar 4. Temuan artefak batu sektor Tana Ugi (skala $1 \mathrm{~cm}$ ). a) artefak beliung; b) artefak serpih bahan chert; c) tembikar (dokumentasi Balar Sulsel, 2014). 
Selain survei, dilakukan pula ekskavasi di bagian lereng Bukit Bakung yang merupakan sektor yang paling banyak memiliki jenis temuan arkeologi dan sebaran cukup merata seperti artefak batu dan fragmen tembikar (gambar 5). Ekskavasi yang dilakukan dengan membuka kotak berukuran $100 \times 200 \mathrm{~cm}$ yang digali dengan teknik spit interval 10 $\mathrm{cm}$. Proses perekaman data tetap memperhatikan posisi temuan pada lapisan tanah. Secara keseluruhan jenis dan jumlah temuan per spit dapat dilihat pada tabel berikut.
Tabel 1 menunjukkan bahwa temuan lebih didominasi oleh tembikar dan kemudian artefak batu. Kesetaraan data tembikar dengan artefak batu mengisi ruang pada hampir setiap spit dalam kotak ekskavasi ini. Secara keseluruhan intensitas temuan semakin banyak pada spit 4, 5 dan $6(50-80 \mathrm{~cm})$. Jumlah temuan paling banyak yaitu pada spit $6(70 \mathrm{~cm})$ berupa fragmen tembikar, artefak batu, tulang dan gigi hewan, manik-manik serta logam. Hal ini membuktikan bahwa pada ketiga spit tersebut $(4,5,6)$ merupakan lapisan yang cukup padat dengan

Tabel 1. Distribusi temuan ekskavasi situs Mallawa sektor Bulu Bakung

(Sumber: Hasil Penelitian, 2014)

\begin{tabular}{|c|c|c|c|c|c|c|c|c|}
\hline \multirow{2}{*}{ No } & \multirow{2}{*}{$\begin{array}{c}\text { Spit } \\
\text { (kedalaman) } \\
\text { dalam } \mathrm{cm}\end{array}$} & \multicolumn{6}{|c|}{ Jenis dan jumlah temuan } & \multirow{2}{*}{ Keterangan } \\
\hline & & Tembikar & $\begin{array}{c}\text { Artefak } \\
\text { Batu }\end{array}$ & $\begin{array}{c}\text { Tulang } \\
\text { binatang }\end{array}$ & $\begin{array}{c}\text { Gigi } \\
\text { binatang }\end{array}$ & $\begin{array}{c}\text { Manik- } \\
\text { manik }\end{array}$ & Logam & \\
\hline 1 & $P$ & 505 & 0 & 0 & 0 & 1 & 0 & \\
\hline 2 & $1(0-30)$ & 522 & 2 & 0 & 0 & 0 & 0 & \\
\hline 3 & $2(30-40)$ & 464 & 2 & 0 & 0 & 0 & 0 & \\
\hline 4 & $3(40-50)$ & 752 & 5 & 1 & 0 & 0 & 0 & \\
\hline 5 & $4(50-60)$ & 1052 & 7 & 1 & 0 & 0 & 0 & \\
\hline 6 & $5(60-70)$ & 1133 & 6 & 1 & 1 & 1 & 1 & \\
\hline 7 & $6(70-80)$ & 910 & 6 & 0 & 0 & 0 & 0 & \\
\hline 8 & $7(80-90)$ & 634 & 6 & 1 & 1 & 0 & 0 & \\
\hline 9 & $8(90-100)$ & 533 & 8 & 2 & 1 & 0 & 0 & \\
\hline 10 & $9(100-110)$ & 263 & 5 & 1 & 0 & 1 & 0 & \\
\hline 11 & $10(110-120)$ & 128 & 1 & 0 & 2 & 0 & 0 & \\
\hline 12 & $11(120-130)$ & 73 & 4 & 0 & 0 & 0 & 0 & \\
\hline 13 & $12(130-140)$ & 47 & 10 & 0 & 0 & 0 & 0 & \\
\hline 14 & $13(140-150)$ & 50 & 7 & 0 & 0 & 0 & 0 & \\
\hline 15 & $14(150-160)$ & 9 & 0 & 0 & 0 & 0 & 0 & \\
\hline 16 & $15(160-170)$ & 0 & 0 & 0 & 0 & 0 & 0 & \\
\hline 17 & $16(170-180)$ & 0 & 2 & 0 & 0 & 0 & 0 & pecah \\
\hline & Jumlah & 7075 & 71 & 7 & 5 & 3 & 1 & \\
\hline
\end{tabular}


kualitas dan kuantitas temuan paling tinggi yaitu memiliki ciri Neolitik seperti artefak batu jenis beliung dan pahat serta tembikar hingga masa Logam Awal. Namun bagaimanapun ke depan masih perlu keselarasan data artefak dan analisis

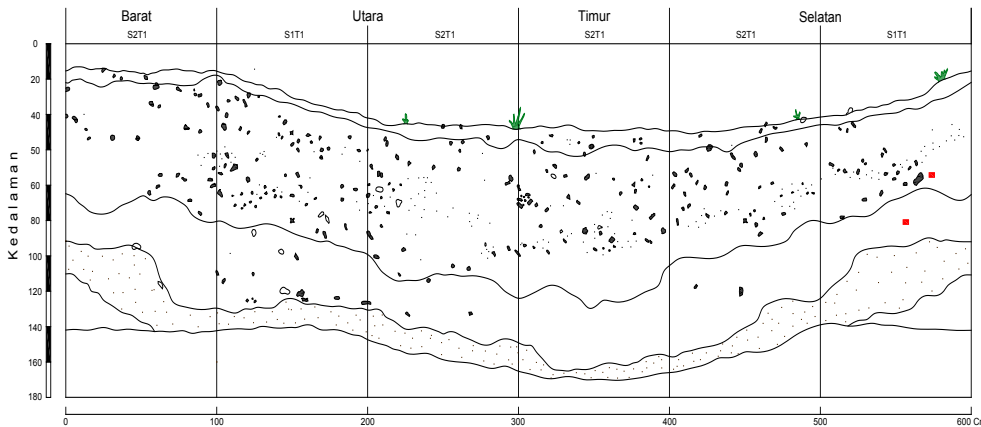
karbon dating pada lapisan tanah dan pada matriks yang sama.

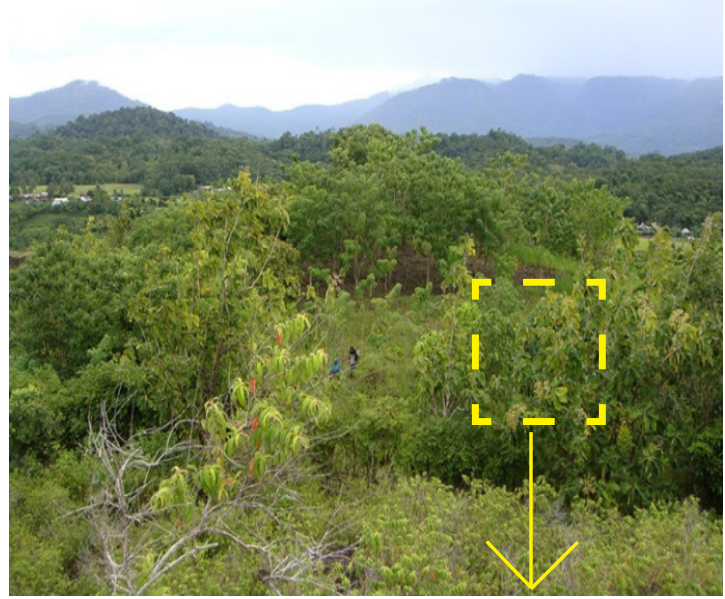

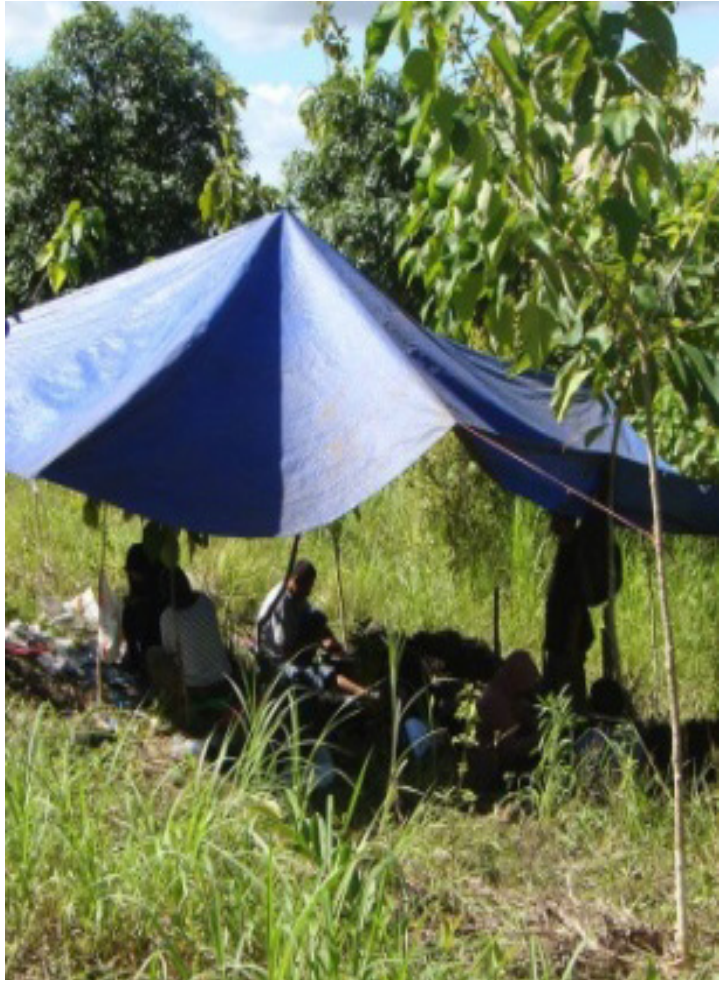

Gambar 5. Lokasi Kotak ekskavasi Situs Mallawa sektor Bulu Bakung (dokumentasi Balar Sulsel, 2014).
Gambar 6. Stratigrafi Kotak Ekskavasi sektor Bulu Bakung (digambar oleh Basran Burhan) (sumber: Hasil Penelitian, 2014).

Ekskavasi yang dilakukan di sektor Bulu Bakung mencapai kedalaman $180 \mathrm{~cm}$ (lihat gambar 6). Secara keseluruhan terdapat lima lapisan hingga mencapai lapisan steril. Namun hanya empat lapisan yang memiliki tinggalan arkeologis. Pengamatan lapisan tanah dilakukan berdasarkan observasi langsung dengan melihat perbedaan ciri-ciri fisiknya seperti warna tanah, tekstur dan sifat tanah. Selain itu juga dilakukan perekaman data temuan yang terletak di setiap lapisan-lapisan tanah tersebut.

Gambar stratigrafi di atas memperlihatkan lima lapisan tanah dalam kotak ekskavasi yang berukuran 100 x $200 \mathrm{~cm}$. Lapisan pertama yaitu top soil atau tanah humus. Warna tanah abu-abu tua kecoklatan dengan tekstur lempung pasiran, sifat tanah gembur dan sedikit lengket, banyak terdapat akar tanaman terutama jenis rumput gajah. Tebal lapisan ini bervariasi, semakin ke timur semakin tebal hingga mencapai $17 \mathrm{~cm}$. Jenis temuan 
didominasi oleh fragmen tembikar baik polos maupun yang memiliki ragam hias. Temuan lain berupa satu manikmanik.

Lapisan kedua tidak banyak memiliki perbedaan dilihat berdasarkan ciri-ciri fisiknya. Warna tanah masih tetap abu-abu gelap kecoklatan dengan tekstur lempung pasiran. Sifat tanah lebih kompak dibandingkan lapisan sebelumnya. Lapisan ini adalah lapisan paling tebal dibandingkan keempat lapisan lainnya yang memiliki temuan arkeologis yaitu mencapai $92 \mathrm{~cm}$ dengan variasi ketebalan yang tidak signifikan. Lapisan ini memiliki temuan arkeologis yang paling tinggi dari segi variabilitas temuannya. Jenis temuan didominasi oleh fragmen tembikar dan artefak batu (termasuk batu pelandas) (gambar 6). Selain itu, ditemukan pula logam, manik-manik, tulang dan gigi binatang.

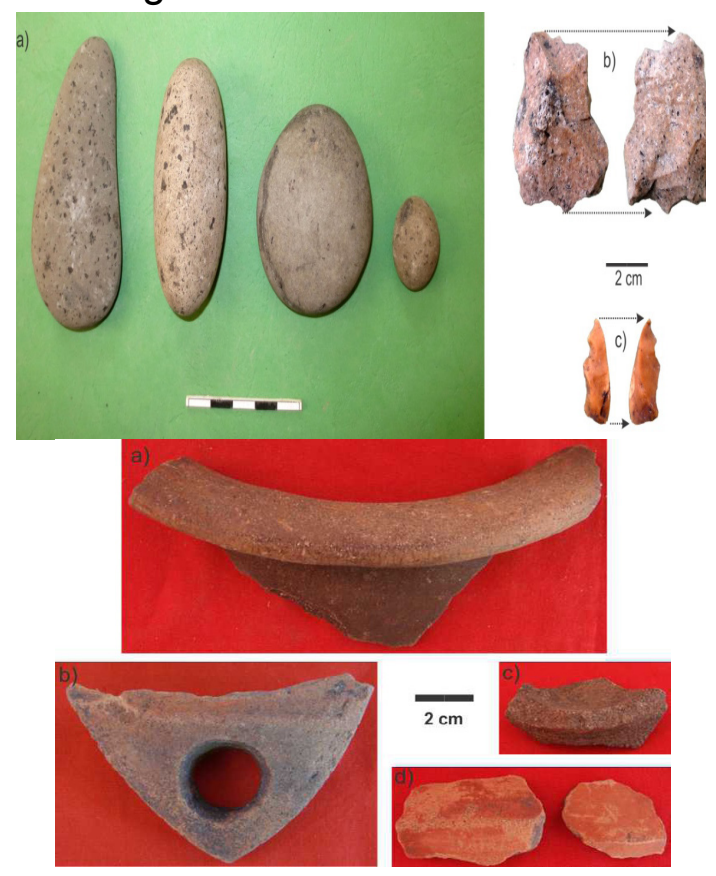

Lapisan ketiga tidak banyak memiliki perbedaan dari lapisan sebelumnya terutama warna tanah. Akan tetapi dari segi tekstur dan sifat tanah sangat berbeda dengan lapisan kedua. Tekstur lempung lebih halus dan tidak banyak mengandung pasiran, sifat tanah lebih gembur dan lebih liat. Lapisan ini memiliki ketebalan $20 \mathrm{~cm}$ hingga $50 \mathrm{~cm}$ dan miring mengikuti kemiringan permukaan kotak. Intensitas dan variabilitas temuan arkeologis berkurang drastis. Jenis temuan berupa fragmen tembikar dan artefak batu. Lapisan ini tidak ditemukan butiran-butiran fragmen tembikar sebagaimana pada lapisan sebelumnya. Selain itu, tidak ditemukan lagi artefak logam dan manik-manik.

Lapisan keempat sangat mudah dibedakan dibandingkan lapisan sebelumnya. Warna tanah lebih terang yaitu abu-abu, tekstur berupa pasir kasar dengan sedikit lempung, sifat tanah sangat gembur dan lembab. Pada lapisan ini tidak mengalami perubahan yang signifikan dari segi temuan-temuan arkeologis baik intensitas maupun variabilitas temuan.

Lapisan kelima adalah lapisan steril dengan ciri-ciri berwarna coklat gelap, sangat padat dan kompak. Jenis tanah liat bercampur kerikil-kerikil batu yang bisa dipecah berwarna coklat kemerahan. Semakin ke bawah lapisan tanah semakin kompak dan keras.

Gambar 6. Sebagian temuan pada lapisan kedua. Fragmen tembikar spit 4, 6, 7, 9, 12 (60-130 $\mathrm{cm}$ ). a). Fragmen tepian; b). Fragmen pegangan; c). Fragmen dasar dengan permukaan kasar; d) Fragmen karinasi slip merah (Kiri). Temuan batu pelandas (kanan) (dokumentasi Balar Sulsel, 2014) 
Hasil Pengukuran XRD, XRF dan SEM terhadap Sampel Tembikar

Dari tabel temuan ekskavasi Mallawa (tabel 1) diketahui bahwa temuan didominasi oleh tembikar yaitu $99 \%$ dari total jenis temuan. Hampir semuan lapisan-permukaan hingga spit 13 mengandung temuan fragmen tembikar berhias baik berslip maupun tanpa slip. Secara umum temuan fragmen tembikar berhias sebanyak $3 \%$ atau 216 fragmen dari 7075 temuan fragmen tembikar. Jumlah ini terus meningkat dari lima fragmen pada permukaan kotak hingga mencapai 39 fragmen pada spit 6 , dan kemudian mengalami penurunan pada spit 7 sebanyak 20 fragmen dan terus berkurang hingga pada spit 13 yang hanya ditemukan dua fragmen. Dari bentuk dan dalamnya irisan dinding dapat diketahui cara teknik pembuatan motif hias tembikar Mallawa yaitu teknik lukis, tekan, gores, cukil, dan tempel. Secara teknis, pembuatan motif dengan menggunakan teknik lukis dapat dilakukan sebelum dan sesudah tembikar dibakar, sedangkan teknik lainnya hanya dapat dilakukan pada saat tembikar belum dibakar.

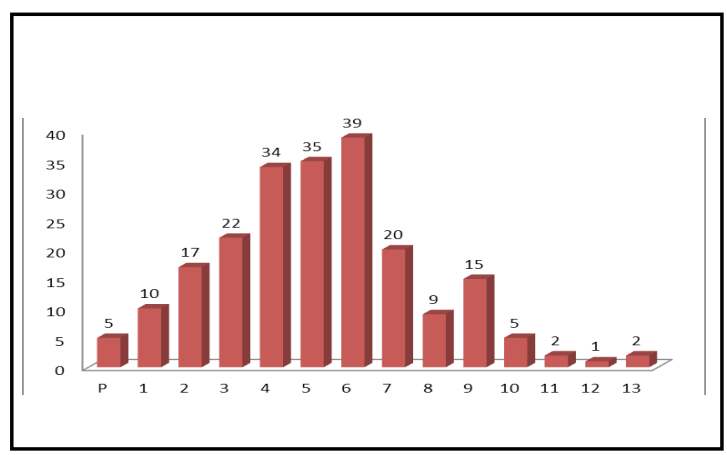

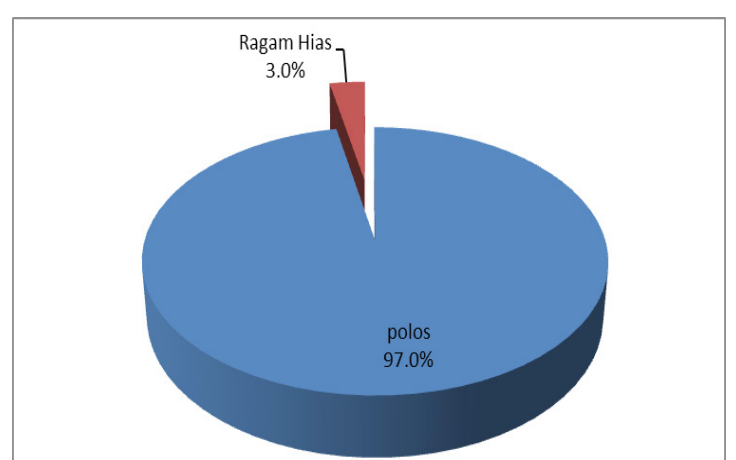

Gambar 7. Diagram temuan tembikar dalam kotak ekskavasi (sumber: Hasil penetitian 2014)

Temuan tembikar merupakan hal yang sangat menarik dikaji untuk mengetahui lokasi asal bahan tanah liat yang digunakan. Dari 7075 temuan, selanjutnya diambil enam sampel tembikar yang mewakili jenis fragmen yaitu dua fragmen slip merah polos (dari kedalaman 90-100 cm), satu sampel slip merah berhias (dari kedalaman $110 \mathrm{~cm}$ ), dua tepian kasar (dari kedalaman 110 dan $150 \mathrm{~cm}$ ), dan satu sampel dasar halus berhias (dari kedalaman $110 \mathrm{~cm}$ ).

Tanah yang dijadikan sampel untuk mengetahui kandungan mineralnya diperoleh dari kedalama 50 $\mathrm{cm}$ (lapisan 2) dan dari kedalaman 70 $\mathrm{cm}$ (lapisan 3). Kedua sampel tanah tersebut mengandung artefak batu dan tembikar yang cukup padat dan pada lapisan itu puladitemukan batupelandas yang biasanya digunakan sebagai alat pembuatan tembikar. Adapun sampel tembikar yang dianalisis dengan XRD dan SEM sebanyak enam sampel. Morfologi permukaan tanah lempung sampel 1 dan 2 diperlihatikan pada gambar berikut. 

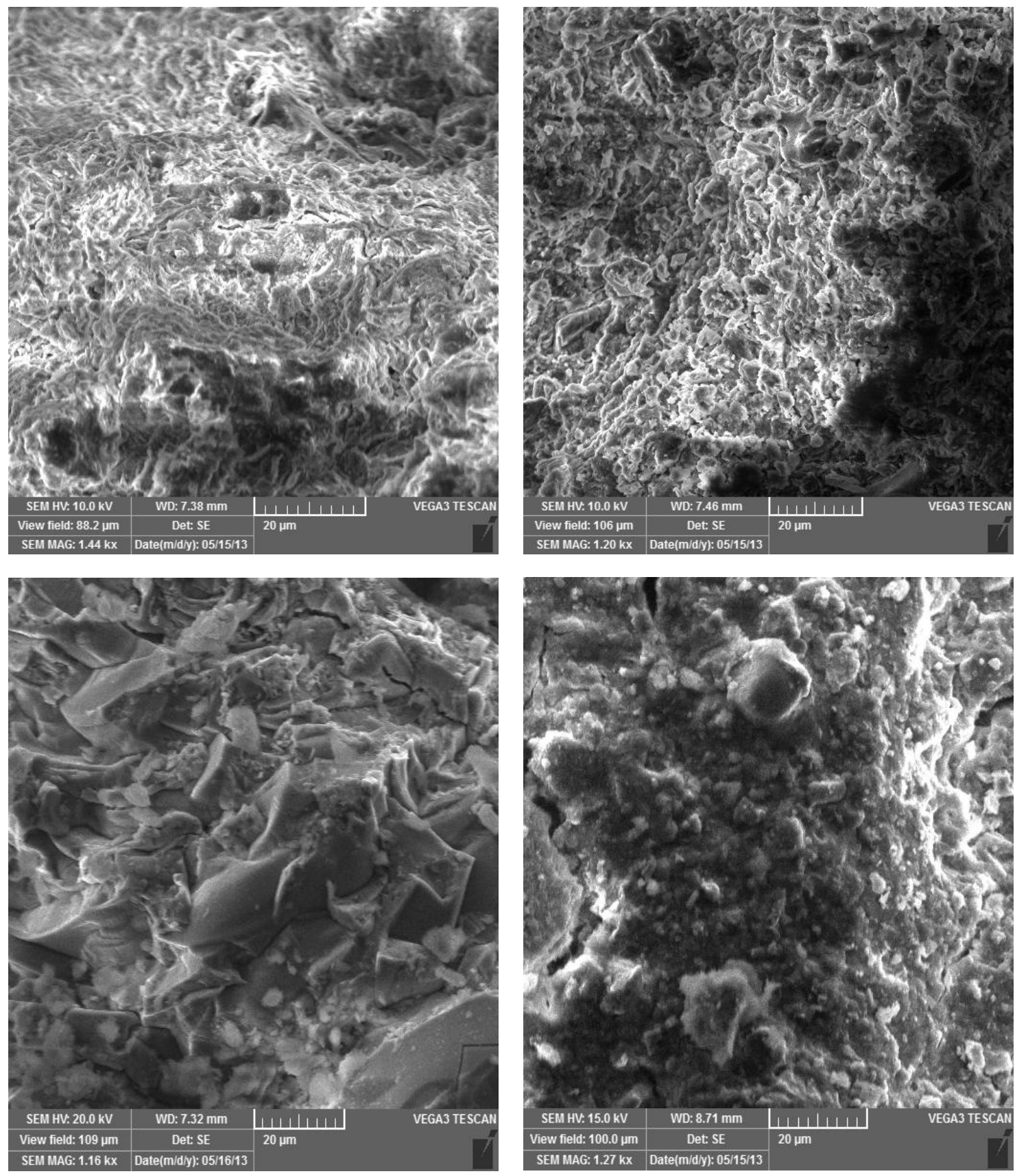

Gambar 8. Morfologi tanah lempung Mallawa, sampel 1 (kiri) dan 2 (kanan) (sumber: Hasil analisis laboratorium Departemen Fisika, Universitas Negeri Makassar 2014)

Gambar di atas memperlihatkan hasil karakterisasi SEM sampel tanah 1 dan 2 bahwa kedua sampel tersebut tergolong atau berasal dari jenis tanah lempung (clays) dengan komposisi kimia $\mathrm{SiO}_{2}$ dan $\mathrm{Al}_{2} \mathrm{O}_{3}$ yang tinggi, masing-masing $49,13 \mathrm{wt} \%$ dan 25,03 wt $\%$ untuk sampel tanah 1 sebesar $52,02 \mathrm{wt} \%$ dan untuk sampel tanah sebesar 224,89 wt\%. Rasio molar kedua oksida tersebut sangat sesuai digunakan sebagai bahan dasar keramik tradisional berkualitas tinggi (Mahnicka, 2012). Oksida lain dengan wt\% paling tinggi yang ditemukan di dalam kedua sampel tersebut secara berurutan adalah $\mathrm{FeO}, \mathrm{CaO}, \mathrm{K}_{2} \mathrm{O}, \mathrm{P}_{2} \mathrm{O} 5$, $\mathrm{MgO}, \mathrm{TiO}_{2}$ dan $\mathrm{Na}_{2} \mathrm{O}$. Oksida seperti ini sesungguhnya tidak diperlukan dalam produksi keramik tradisional dan pada 
umumnya bersifat sebagai pengotor.

Selanjutnya, hasil pengukuran SEM untuk sampel keramik, Spit 7 slip merah, Spit 8 slip merah, Spit 9 tepian kasar, Spit 9 slip merah berhias, Spit 9 kaki halus berhias dan Spit 13 tepian kasar memperlihatkan komposisi kimia ( $w t \%$ oksida) yang tepat sama dengan kandungan komposisi Kimia sampel tanah 1 dan 2. Perbandingan komposisi kimia (wt\% oksida) atau mineral penyusun setiap sampel (slip merah dan tepian kasar) dapat dilihat pada hasil $X$-Ray Fluorescence (XRF). Hasil XRF juga memperlihatkan bahwa seluruh mineral yang dikandung sampel tanah Mallawa 1 dan sampel tanah Mallawa 2 juga ditemukan pada seluruh sampel tembikar (slip merah dan tepian kasar) dan tidak ditemukan adanya mineral lain yang mengisi matriks tembikar tersebut. Kesesuaian ini menunjukkan bahwa sampel tembikar tersebut dibuat atau diproduksi dengan menggunakan tanah lempung dari jenis sampel tanah satu atau sampel tanah dua.

Demikian pula dengan hasil analisis dengan pengukuran $X$-Ray Diffraction (XRD) terhadap sampel tanah 1 dan 2 memperlihatkan bahwa tipe lempung yang dikandung oleh sampel tanah 1 adalah tipe kaolinite $\left(\mathrm{Al}_{2}\left(\mathrm{Si}_{2} \mathrm{O}_{5}\right)(\mathrm{OH})_{4}\right)$ dan sanidine (Na.56 K3.44 Al4 Si12 O32), sedangkan untuk sampel tanah 2 terdiri atas sanidine dan potassium sodium calcium aluminium iron alumotitanosilicate hydroxide (K0.776 Na0.181 Ca0.011) (Al0.916
Fe0.016 Mg0.011)2 (Si0.787 Al0.223 Ti0.005)4. Perbedaan senyawa kimia ini menunjukkan bahwa sumber kedalaman pengambilan sampel berbeda. Kaolin pada umumnya hanya ditemukan hingga kedalaman 3 meter dari permukaan tanah.

Pada sampel Spit 7 slip merah, Spit 8 slip merah, Spit 9 slip merah berhias, Spit 9 kaki halus berhias didominasi oleh sejumlah fase berikut: nepheline, mullite, orthoclase dan anothoclase. Kehadiran fase seperti ini hanya dimungkinkan bila bahan dasar tembikar (clay minerals) mengalami pembakaran pada temperatur antara $1000^{\circ} \mathrm{C}-1300^{\circ} \mathrm{C}$ minimum 6 jam dengan laju pemanasan (heating rate) yang rendah. Pada sampel Spit 9 Tepian Kasar tidak ditemukan fase mullite, orthoclase atau anorthoclase. Hal ini menunjukkan bahwa temperatur produksi sampel ini di bawah $750^{\circ}$ C. Berbeda dengan sampel Spit 13 Tepian Kasar yang mengandung fase mullite dan orthoclase yang merupakan indikasi perubahan senyawa mineral akibat perlakuan panas yang tinggi atau temperatur di atas $1000^{\circ} \mathrm{C}$ (Leonard, et. al., 2004; Subaer, 2012).

\section{PEMBAHASAN}

Penelitian yang telah dilakukan di Mallawa menghasilkan jenis temuan yang sangat bervariasi dari jenis dan bentuknya. Secara umum, sebaran temuan secara vertikal tidak memperlihat karakteristik yang signifikan. Hal tersebut terlihat pada 
temuan artefak dari bahan batuan chert yang hampir ditemukan pada semua lapisan tanah. Demikian juga dengan temuan artefak beliung dan serpih dari bahan batuan sabak, basalt dan gamping yang memiliki sebaran temuan merata pada setiap lapisan tanah. Keseluruhan jenis batuan tersebut cukup tersebar di sekitar situs Mallawa. Dari sejumlah penelitian itu diketahui bahwa jenis batu yang digunakan sebagai artefak berasal dari jenis batuan yang banyak ditemukan di sekitar lokasi situs. Dengan demikian manusia pendukung kebudayaannya telah memanfaatkan sumberdaya batuan yang ada di sekitarnya dipergunakan sebagai bahan baku maupun sebagai sarana pembuatan alat. Hasil yang diperoleh itu juga menegaskan tentang variasi artefak batu berupa kapak dan beliung serta sebaran fragmen tembikar yang cukup padat di beberapa situs di kawasan Mallawa.

Secara periodesasi, situs Mallawa lebih muda dari masa hunian gua-gua Maros. Namun mungkin sekali hunian di Mallawa merupakan kehidupan selanjutnya dengan mengembangkan budaya yang materialnya cukup tersedia di sekitarnya. Pada tempattempat tertentu, terutama di muara, kelompok manusia berbahasa Austronesia memeriksa ketersediaan sumber daya alam, dan kemudian mereka memasuki daerah pedalaman dengan memanfaatkan sungai sebagai pusat orientasi rute pelayaran
(Mahmud, 2008: 125-126).

Temuan batu pelandas yang biasanya digunakan sebagai alat untuk meratakan dan membentuk badan dalam proses pembuatan tembikar, ditemukan pada kedalaman $60 \mathrm{~cm}$ hingga $130 \mathrm{~cm}$ (spit 12). Artinya jenis temuan tersebut beasosiasi dengan fragmen tembikar pada lapisan yang sama. Tembikar juga ditemukan pada semua lapisan, baik permukaan kasar maupun halus. Akan tetapi tembikar berslip merah hanya ditemukan hingga spit 12 atau pada kedalaman $130 \mathrm{~cm}$. Begitupun dengan temuan fragmen logam dan manik-manik, hanya terdapat hingga pada lapisan yang kedua. Namun sangat disadari bahwa belum dilakukan analisis bentuk wadah dari fragmen tembikar yang ada. Analisis tembikar hanya difokuskan pada kandungan mineral untuk memastikan bahwa wadah tembikar yang ditemukan diproduksi di sekitar situs Mallawa atau juga mungkin di luar radius situs Mallawa, atau dengan perkataan lain bukan merupakan barang impor. Oleh karena itu, tulisan ini lebih mempertegas pemanfaatan sumber daya lokal dalam pembuatan peralatan dalam menunjang kebutuhan hidup manusia di Mallawa pada era Neolitik. Pembahasan lebih difokuskan pada hasil analisis kandungan mineral tembikar dan sampel tanah yang diperoleh dari hasil ekskavasi untuk mengetahui asal dan bahan pembuatannya. 
Berdasarkan hasil analisis terhadap temuan fragmen tembikar dan artefak batu menunjukkan bahwa terdapat kesamaan dari segi bentuk dan teknologi dengan situssitus yang terdapat di Kalumpang (Minanga Sipakko dan Kamansi). Hal ini menunjukkan bahwa ada kesamaan dalam pola adaptasi dengan pemanfaatan sumber batuan yang ada di sekitar permukiman mereka untuk dijadikan sebagai alat dalam menunjang kebutuhan hidup manusia (Mahmud, 2008: 126). Hasil analisis mineral terhadap kandungan mineral tanah yang terdapat pada lapisan budaya dalam kotak ekskavasi dengan kandungan mineral yang terkandung dalam tembikar menunjukkan bahwa ada kesamaan kandungan mineral keduanya sehingga dapat disimpulkan bahwa tembikar tersebut dibuat dan diproduksi di sekitar wilayah Mallawa. Namun sampel penelitian hanya diperoleh di Bukit Bakung, sementara masih tersisa sekitar dua bukit yang memiliki bentuk topografi yang sama. Hasil yang dicapai kali ini belum mampu menjelaskan secara keseluruhan karena fokus penelitian ini masih terfokus pada Bulu Bakung. Sebagai proyeksi ke depan, masih perlu pengujian sampel tanah dari luar radius situs Mallawa sebagai komparasi untuk memastikan produksi tembikar Mallawa.

Apabila mencermati perkembangan kehidupan manusia melalui peninggalan arkeologi, terilihat bahwa manusia melalui kebudayaannya senantiasa berusaha merespon lingkungan alam di sekitarnya. Manusia senantiasa berusaha untuk menyesuaikan diri dengan lingkungannya. Dalam memanfaatkan sumber alam di sekitarnya untuk memenuhi keperluan hidup, manusia menggunakan caracara yang sangat mempertimbangkan ekologi (Mundardjito, 1993: 234). Pertimbangan ekologi berkaitan dengan keadaan lereng tanah, sumber air, ketinggian, struktur dan tekstur tanah, permukaan tanah sertaketersediaan bahan dan sumber makanan (Mundardjito, 1993:21).

Temuan kapak batu, beliung, manik-manik dan fragmen tembikar semakin menegaskan karakter situs Mallawa sebagai situs permukiman Neolitik yang penting di wilayah timur Indonesia. Temuan tembikar dan beliung batu merupakan salah satu bukti kuat adanya ekspansi kelompok imigran Austronesia di wilayah Sulawesi Selatan (Simanjuntak, et. al., 2012: 266). Teknologi pembuatan dan pemakaian wadah tembikar yang diperkenalkan oleh kelompok penutur Austronesia, dihubungkan dengan dimulainya tradisi bercocok tanam dan domestikasi hewan. Tradisi itu telah diperkenalkan di Sulawesi Selatan sekitar 4000 yang lalu oleh para imigran penutur bahasa Austronesia (Simanjuntak, 2008; Bellwood, 1985: 232). 
Berbagai jenis tembikar yang ditemukan seperti slip merah dan memiliki pola hias berupa goresan cukup banyak ditemukan di Mallawa. Tradisi pembuatan dan penggunaan tembikar sangat ditunjang oleh kondisi geografis Mallawa, Maros yang memiliki jenis tanah alluvial (clay minerals) yang cocok untuk pembuatannya. Dari klasifikasi temuan fragmen tembikar jelas bahwa aktivitas mengolah bahan makanan (seperti periuk dan mangkuk) lebih tinggi frekuensinya. Hal itu sekaligus mengindikasikan adanya sistem permukiman di daerah terbuka. Sisa-sisa kegiatan manusia yang terdapat pada situs tersebut merupakan indikator penting adanya komunitas yang pernah bermukim di

\section{PENUTUP}

Penelitian di situs Neolitik Mallawa Maros, Sulawesi Selatan dilakukan di sektor Bulu Bakung dan Tana Ugi. Berdasarkan temuan artefaktual dan pertanggalan radiokarbonmembuktikan sebagai situs hunian manusia yang berlangsung pada $3580 \pm 130 \mathrm{BP}$ dan $2710 \pm 170$ BP sampai $2281 \pm 46$ BP. Penghuni Mallawa menempati areal yang terbuka dengan mengandalkan sumber bahan batuan yang tersedia dan ditunjang oleh sumber air dari sungai yang mengalir di sekitar situs. Hasil analisis bahan batuan yang digunakan untuk pembuatan artefak menunjukkan cukup tersedianya bahan
Mallawa (Subroto, 1983:1176). Hasil analisis terhadap sejumlah fragmen (baik temuan survei maupun temuan ekskavasi) sebagian besar di antaranya menunjukkan bekas pemakaian seperti terdapatnya bekas pembakaran pada bagian permukaan tembikar dan juga bentuk wadah yang besar seperti tempayan. Sejumlah aktivitas dapat tergambar dari hasil analisis fragmen tembikar, bahwa beberapa bentuk seperti periuk memegang peranan yang sangat penting untuk memenuhi kebutuhan rumah tangga, demikian pula halnya dengan tempayan yang kegunaannya hingga kini masih berlangsung seperti digunakan untuk wadah menampung air.

di sekitar situs. Hal tersebut dibuktikan dengan dukungan data geologi dan temuan artefak batu dari bahan basalt, sabak, chert (rijang) dan gamping. Analisis XRD, XRF dan SEM terhadap fragmen tembikar menunjukkan bahwa kandungan sampel tanah memiliki kesamaan unsur kimia dengan kandungan bahan tembikar. Hal ini menunjukkan bahwa tembikar tersebut diproduksi di Mallawa dan sekitarnya yang berarti pula bahwa masyarakat memanfaatkan bahan yang tersedia di lingkungan sekitarnya untuk membuat peralatan untuk menunjang hidupnya. 


\section{DAFTAR PUSTAKA}

Aubert M., A, Brumm, M. Ramli, T. Sutikna, E.W. Saptomo, B. Hakim, M. J. Morwood, G. D. van den Berg., I. Kinsley, A. Dosseto. 2014. "Pleistocene Cave Art from Sulawesi, Indonesia”. Journal of Nature. 514:223-227.

Bellwood, Peter. 1985. Prehistory of the Indo-Malaysian Archipelago. London: Academic Press.

Fadhlan S.I., dkk. 1995. "Keadaan Geologi dan Peninggalan Arkeologi Situs , Kabupaten Maros Propinsi Sulawesi Selatan". Laporan Penelitian Balai Arkeologi Ujung Pandang (belum terbit).

Fadhlan S.I., dkk. 2012. "Pemetaan Potensi Situs-situs Gua di Kawasan Karst MarosPangkep, Sulawesi Selatan, Kajian Arkeologi Publik Tahap I". Laporan penelitian Arkeologi. Jakarta: Pusat Arkeologi Nasional (belum terbit).

Hakim, Budianto, Muhammad Nur, Rustam. 2009. "The Sites of Gua Pasaung (Rammang-Rammang) and Indicators of Cultural Contact Between The Toalian and Neolithic Complexes in South Sulawesi". IPPA Bulletin 29. 2009: 45-52.

Leonard, D. Akwilapo and Kjell Wiik. 2004. "Ceramic Properties of Pugu Kaolin Clays, Part 2: Effect of Phase Composition on Flexural Strength". Bull. Chem. Soc. Ethiop 18(1), 7-16.

Mahmud, Irfan. 2008. "The Neolithic Site of" in Austronesian in Sulawesi, p. 119127. Jakarta: Center for Prehistoric and Austronesian Studies.

Mahnicka, L. 2012. "Influence of Raw Materials Ratio and Sintering Temperature on the Properties of the Refractory Mullite-Corundum Ceramics, World Academy of Science". Engineering and Technology 63.

Mundardjito. 1993. "Pertimbangan Ekologi dalam Penempatan Situs Masa HinduBuda di Daerah Yogyakarta: Kajian Arkeologi Ruang Skala Makro". Disertasi, Fakultas Sastra Universitas Indonesia.

Simanjuntak, Harry T. (ed). 2008. Austronesian in Sulawesi. Jakarta: Center for Prehistoric and Austronesian Studies.

Simanjuntak, Harry T. dan Widianto, Harry (ed.) 2012. Indonesia dalam Arus Sejarah. Jakarta: PT. Ichtiar Baru van Hoeve.

Subaer. 2012. Pengantar Fisika Geopolimer. Jakarta: Kementerian Pendidikan Tinggi.

Subroto, Ph. 1983. "Studi tentang Pola Permukiman Arkeologi: Kemungkinankemungkinan Penerapannya di Indonesia" Pertemuan IImiah Arkeologi III. Jakarta: Pusat Penelitian Arkeologi Nasional.

Tim BPCB Sulsel. 2012. "Laporan Survei Penyelamatan Situs Neolitik". Makassar: Balai Pelestarian Cagar Budaya (belum terbit).

Tim Balar Sulsel. 2014. "Laporan Penelitian Arkeologi Situs Neolitik Mallawa, Kabupaten Maros" (belum terbit). 